\title{
Antioxidant activity of water-soluble polysaccharide extracts produced from perilla seed cake by enzymatic hydrolysis
}

\author{
Yeo Jin Hwang ${ }^{\ddagger}$, Ja Min Kim ${ }^{\ddagger}$, Kyung Young Yoon* \\ Department of Food and Nutrition, Yeungnam University, Gyeongsan 38541, Korea
}

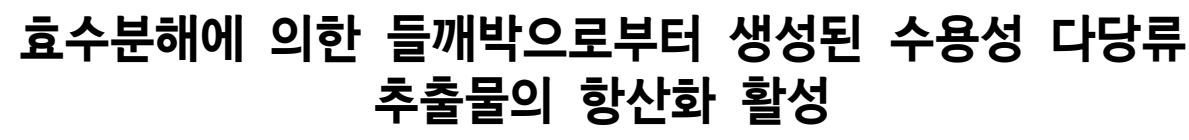

\author{
황여진 ${ }^{\ddagger} \cdot$ 김자민 $^{\ddagger} \cdot$ 윤경영* \\ 영남대학교 식품영양학과
}

\begin{abstract}
This study was conducted for the production of water-soluble polysaccharide (WSP) extracts from perilla seed cake (PSC), a byproduct of food processing, by using commercial enzymes. PSC was divided into cellulose fraction (CF) and hemicellulose fraction (HF), and the enzymatic hydrolysis conditions of each fraction were determined for the production of WSP extracts. Afterwards, the antioxidant activity of these WSP extracts was measured. The hydrolysis conditions of the CF for producing WSP extracts were $\mathrm{pH} 5.0,50^{\circ} \mathrm{C}$, and 30 units of Celluclast while those of HF were $\mathrm{pH} 4.0,50^{\circ} \mathrm{C}$, and 30 units of Viscozyme. The yield of WSP extracts increased from $176 \mathrm{~g} / \mathrm{kg}$ at $0 \mathrm{~h}$ of hydrolysis to $233.1 \mathrm{~g} / \mathrm{kg}$ after $72 \mathrm{~h}$ of hydrolysis. Futhermore, the polyphenol content of WSP extracts from CF and HF were significantly higher after enzymatic hydrolysis for $24 \mathrm{~h}$, but decreased after $48 \mathrm{~h}$ of hydrolysis. In addtion, WSP extracts obtained after $24 \mathrm{~h}$ of hydolysis showed the lowest $\mathrm{IC}_{50}$ values for hydroxy radical scavenging activity, reducing power activity, and superoxide dismutase-like activity. From the result, WSP extracts with antioxidant activity could be effectively extracted by enzymatic hydrolysis, and the extracts are considered to be used as a functional substance in the food industry.
\end{abstract}

Key words : perilla seed cake, agricultural by-product, water-soluble polysaccharides, antioxidant activity, enzymatic hydrolysis

서 론

최근 국민소득의 증가와 함께 외식 및 가공식품 섭취에 따 른 식생활 변화로 영양과잉 및 영양불균형이 유발되고, 당뇨 병, 비만, 고혈압 및 고지혈증과 같은 만성질환의 발병률이 증가되고 있다(Moon 등, 2019). 이에 국민들의 건강에 대한 우려가 깊어져 건강기능성 식품의 소비가 증가하고 있으며,
특히 다양한 생리기능성을 가진 식물성 식품에 대한 관심이 높아지는 추세이다(Lee 등, 2015). 식물성 식품은 식이섬유 를 비롯한 난소화성 다당류를 많이 함유하고 있으며, 식이섬 유가 각종 질병들의 예방 및 완화효과를 가지는 것으로 밝혀 져 건강기능성 식품소재로 주목받고 있다(Lembod와 Camilleri, 2003). 또한 식이섬유는 다양한 물리적 특성을 가져 식품의 관능적 특성을 향상시키기 위한 목적으로 식품산업에서 많이

\footnotetext{
*Corresponding author. E-mail : yoonky2441@ynu.ac.kr, Phone : +82-53-810-2878, Fax : +82-53-810-4666

${ }^{\ddagger}$ These authors contributed equally to this work.

Received 24 August 2020; Revised 06 October 2020; Accepted 07 October 2020.

Copyright (c) The Korean Society of Food Preservation.

This is an Open Access article distributed under the terms of the Creative Commons Attribution Non-Commercial License (http://creativecommons.org/licenses/by-nc/4.0) which permits unrestricted non-commercial use, distribution, and reproduction in any medium, provided the original work is properly cited.
} 
이용되고 있다(Choi와 Kim, 1992).

들깨(Perilla frutescens var. japonica Hara)는 한국 - 중 국 · 일본 등지에서 자라는 한해살이풀 또는 그 씨를 의미하 며, 독특한 향을 가져 잎의 식용뿐만 아니라 유료작물의 목적 으로 많이 재배된다. 들깨유는 $\omega-3$ 계 다가불포화지방산의 함 량이 높고 대장암 및 폐암 완화, 항염증 및 인지기능 장애 개 선 등 다양한 생리활성 효능이 있는 것으로 보고되고 있다 (Lee 등, 2014). 들깨유의 우수한 생리기능성으로 생산과 소 비가 증가하고 있는 추세이며, 2010년 약 1,500 톤이었던 들 기름의 생산량이 2019년에는 4,400톤으로 크게 증가하였다 (Ministry of Food and Drug Safety, 2011; 2020). 이에 따라 들깨유 착유 공정 중 생산되는 들깨박의 발생은 매년 증가하 고 있으며, 일부가 가축 사료로 이용되고 있으나 대부분 폐기 처리 되고 있다(Kim 등, 2019).

이와 같이 식품 가공과정 중에 발생하는 농산가공 부산물 은 난소화성 물질로 이루어진 고분자 화합물인 식이섬유를 포함한 단백질 및 생리활성 물질들을 함유하고 있어 기능성 식품소재로서의 활용가능성이 매우 높다(Di Bernardini 등, 2011). 그러나 이들 성분은 용해력이 낮아 추출률을 높이기 위한 다양한 방법들이 시도되고 있으며, 최근에는 효소를 이 용한 생물학적인 추출방법에 관한 연구가 진행되고 있다. 효 소적 추출방법은 불용성의 고분자 화합물을 수용성의 저분자 화합물로 전화시키는 방법으로, 공정이 복잡하고 인체 유해 성의 문제가 있는 물리적 및 화학적 가수분해 방식과 달리, 기질 특이성에 의해 목표 기질에만 반응하여 기타 부산물의 생산이 비교적 적게 발생하여 균일한 분해액을 추출할 수 있 다(Im 등, 2016). 또한, 기질 농도, 분해시간, 분해온도, $\mathrm{pH}$ 등의 조건을 달리함에 따라 얻고자 하는 분해액을 추출할 수 있다(Hwang과 Yoon, 2020). 따라서 생물학적 가수분해 방법 인 효소를 이용하여 저분자화 시키고, 수용성의 추출물을 생 산하고, 이들의 기능적 특성에 관한 연구가 많이 보고되고 있 다. 참죽에 다양한 세포벽 분해효소를 처리하여 얻은 추출물 이 효소를 처리하지 않고 얻은 추출물에 비해 높은 폴리페놀 함량과 항산화활성을 보였으며(Oh 등, 2015), 불등풀가사리 를 기질로 Viscozyme을 포함한 5종의 상업용 효소를 처리하 여 다당류를 추출한 결과, 효소분해에 의해 다당류의 수율이 증가하였고, 이들 다당류는 높은 항산화 활성, 항염 및 항암 효과를 가지는 것으로 보고되었다(Lee와 Hong, 2017). 또한 메밀껍질로부터 Celluclast 및 Viscozyme을 이용하여 효소분 해하여 수용성 식이섬유소를 생산할 수 있었으며, 이들 식이 섬유소는 포도당 및 담즙산의 흡수를 저해하고, 항산화 효과 를 가지는 것으로 나타났다(Im 등, 2016).

따라서 본 연구는 들깨유 가공공정의 부산물인 들깨박을 기능성 식품소재로 활용하기 위한 기초자료를 제공할 목적으
로 효소분해를 이용하여 수용성 다당류 함유 추출물을 생산 하고자 하였다. 이를 위해 가수분해 효율을 높일 수 있는 세 포벽 분해효소를 선정하고, 선정된 효소의 최적 가수분해조 건을 찾고자 하였다. 또한 최적조건으로 생산된 수용성 다당 류 추출물의 기능성을 확인하기 위한 기초실험으로 항산화 활성을 측정하였다.

\section{재료 및 방법}

\section{실험재료}

본 실험에 사용한 들깨박은 전북 고창에서 재배된 것으로 크기와 외관이 균일한 들깨(Perilla frutescens var. japonica Hara)를 $70^{\circ} \mathrm{C}$ 미만에서 냉압착(cold pressing) 기법으로 착유 하고 남은 부산물을 쿠엔즈버킷(Seoul, Korea)에서 제공받아 실험에 사용하였다. 들깨박으로부터 수용성 다당류 추출물을 생산하기 위해 선행 연구(Gibbins, 2012; Hwang과 Yoon, 2020; Im 등, 2016; Im과 Yoon, 2015; Liu 등, 2008; Park과 Yoon, 2015)에서 주로 사용된 5종의 세포벽 가수분해효소즉, amyoglucosidase(AMG) 300 L, Celluclast 1.5 L, Pectinex Ultra SP-L, Shearzyme plus, 및 Viscozyme L(Novozymes $\mathrm{A} / \mathrm{S}$, Bagsvaerd, Denmark)을 선정하였다. 각 효소의 특성 및 활성 범위는 각각 Table 1에 나타내었으며, 세포벽 분해정도를 확인하기 위하여 celluase 및 hemicellulase 활성을 측정하였다. 즉, cellulase 효소활성은 carboxymethylcellulose $(\mathrm{CMC}$, SigmaAldrich Co., St. Louis, MO, USA)의 분해량으로 측정하였으 며, cellulase 효소활성 1 unit은 $\mathrm{pH} 5.0$ 및 $50^{\circ} \mathrm{C}$ 에서 1분 동안 생성된 glucose의 $\mu$ mole 수로 나타내었다. Hemicellulase 효 소활성은 xylan(Sigma-Aldrich Co.)의 분해량으로 측정하였 으며, hemicellulase 효소활성 1 unit은 $\mathrm{pH} 5.0$ 및 $50^{\circ} \mathrm{C}$ 에서 1 분 동안 생성된 xylose의 $\mu$ mole 수로 나타내었다.

\section{들깨박의 cellulose 및 hemicellulose 분획}

식물 세포벽의 다당류 중 cellulose를 제외한 나머지를 hemicellulose라고 총칭한다. Hemicellulose는 알칼리에 용해 되는 특성을 가지므로 Im과 Yoon(2015)의 방법에 따라 들깨 박으로부터 분획하였다. 즉, 들깨박 $37.5 \mathrm{~g}$ 당 $1 \mathrm{M} \mathrm{NaOH} 500$ $\mathrm{mL}$ 를 가하고, shaking incubator(BS-11, JeioTech, Seoul, Korea)를 이용하여 $25^{\circ} \mathrm{C}, 250 \times \mathrm{g}$ 에서 3 시간 교반하였다. 반 응액을 원심분리(Supra-21K, Hanil, Incheon, Korea)하여 여 과지(Whatman No.2, Maidstone, England)를 이용하여 상등 액과 잔사로 분리한 후, 상등액은 $\mathrm{HCl}$ 로 $\mathrm{pH} 7.0$ 이 될 때까지 중화하여 hemicellulose 분획으로 사용하였다. 또한 잔사는 $\mathrm{pH}$ 7.0 이 될 때까지 증류수로 세척하고 동결건조(FD-1, Eyela, Tokyo, Japan)한 후 $-40^{\circ} \mathrm{C}$ deep freezer(MDF-415, Sanyo, 
Table 1. Characteristics and activity of various cell-wall degrading enzymes used in the study

\begin{tabular}{|c|c|c|c|c|c|c|}
\hline \multirow{2}{*}{ Enzyme } & \multicolumn{4}{|c|}{ Characteristics } & \multicolumn{2}{|c|}{$\begin{array}{l}\text { Experimental activity } \\
\text { (unit } / \mathrm{mL})^{1)}\end{array}$} \\
\hline & Sources & Optimal pH & $\begin{array}{c}\text { Optimal } \\
\text { temperature } \\
\left({ }^{\circ} \mathrm{C}\right)\end{array}$ & Enzyme activity & Cellulase & Hemicellulase \\
\hline AMG $300 \mathrm{~L}$ & Aspergillus niger & 4.5 & 60 & Glucoamylase & $121.2 \pm 7.6^{2)}$ & $129.1 \pm 2.8$ \\
\hline Celluclast $1.5 \mathrm{~L}$ & Trichoderma reesei & $4.5-6.0$ & $50-60$ & Cellulase & $200.5 \pm 5.5$ & $645.3 \pm 27.3$ \\
\hline Pectinex Ultra SP-L & Aspergillus aculeatus & & & Polygalacturonase & $139.7 \pm 13.3$ & $67.1 \pm 5.8$ \\
\hline Shearzyme pluse & Trichoderma reesei & $4.5-6.0$ & $50-60$ & Cellulase & $136.2 \pm 13.6$ & $508.4 \pm 16.3$ \\
\hline Viscozyme L & Aspergillus aculeatus & $3.5-5.5$ & $25-55$ & $\begin{array}{c}\text { Arabanase, cellulase } \\
\beta \text {-glucanase, } \\
\text { hemicellulase, } \\
\text { xylanase }\end{array}$ & $376.7 \pm 6.1$ & $255.8 \pm 25.8$ \\
\hline
\end{tabular}

Tokyo, Japan)하여 cellulose 분획으로 사용하였다.

\section{Cellulose 및 hemicellulose 분획의 효소적 가수분해조건 선정}

Cellulose 및 hemicellulose 분획물에 대해 가수분해력이 가장 높은 효소를 선정하기 위해 $\mathrm{pH} 5.0^{\circ}, 50^{\circ} \mathrm{C}$, 효소 25 unit 의 조건에서 24시간 동안 효소분해 하였다. 그 후, cellulose 분획의 효소가수분해 반응 후 생성된 glucose 함량과 hemicellulose 분획의 효소가수분해 반응 후 생성된 xylose 함량을 $\mathrm{DNS}$ 법으로 측정하여 가장 분해력이 높은 효소를 각각 결정 하였다.

선정된 효소를 이용하여 들깨박 cellulose 분획의 가수분해 최적 조건을 결정하기 위해 기질농도 $4 \%(\mathrm{w} / \mathrm{v})$ 에 $\mathrm{pH}(3.0$, $4.0,5.0,6.0,7.0)$, 온도 $\left(30,40,50,60^{\circ} \mathrm{C}\right)$ 및 효소 농도( 15 , $20,25,30,35$ unit)를 조절하여 가수분해반응 후 생성된 glucose 양을 DNS법으로 측정하였다. 각 반응액은 citrate buffer( $\mathrm{pH}$ 3.0), sodium acetate buffer( $\mathrm{pH}$ 4.0-5.0), potassium phosphate buffer( $\mathrm{pH}$ 6.0-7.0)를 사용하여 $\mathrm{pH}$ 를 조절하였다. 선정된 효소를 이용하여 hemicellulose 분획의 가수분해 최적 조건을 선정하기 위해 $\mathrm{pH}(3.0,4.0,5.0,6.0,7.0)$, 온도(30, $\left.40,50,60^{\circ} \mathrm{C}\right)$ 및 효소 농도 $(15,20,25,30,35$ unit)를 달리하 여 효소 반응을 한 후 생성된 xylose를 DNS법으로 측정하여 비교하였다. 각 $\mathrm{pH}$ 는 $1 \mathrm{M} \mathrm{HCl}$ 을 사용하여 조절하였으며, 분 해액 $25 \mathrm{~mL}$ 를 효소분해 반응에 사용하였다.

\section{수용성 다당류 추출물 제조를 위한 효소가수분해}

들깨박으로부터 수용성 다당류 추출물을 생산하기 위해 효소가수분해를 하였으며, cellulose 분획과 hemicellulose 분
획의 최적 분해조건 하에서 $0,24,48,72$ 시간 동안 효소분해 를 실시하였다. 즉, cellulose 분획 $20 \mathrm{~g}$ 을 $500 \mathrm{~mL}$ 의 $50 \mathrm{mM}$ sodium acetate buffer( $\mathrm{pH} 5.0)$ 에 넣어 $50^{\circ} \mathrm{C}$ 에서 shaking incubator(BS-11, JeioTech, Seoul, Korea)로 24시간 동안 swelling 하였다. 그 후, 30 unit의 Celluclast(Novozymes $\mathrm{A} / \mathrm{S}$ )를 첨가하여 $50^{\circ} \mathrm{C}$ 에서 $250 \times \mathrm{g}$ 로 $0,24,48,72$ 시간 동안 효소분해 하였다. Hemicellulose 분획의 효소분해는 $\mathrm{pH} 4.0$ 으로 조절한 hemicellulose 분획 $500 \mathrm{~mL}$ 를 최적온도 $\left(50^{\circ} \mathrm{C}\right)$ 로 맞춘 후, Viscozyme 30 unit을 첨가하여 $0,24,48,72$ 시간 동안 효소분해 하였다. 효소반응을 끝낸 분해액은 $90^{\circ} \mathrm{C}$ 인 water bath에서 10 분간 가열하여 효소를 불활성화시켰다. 다 음 분해액을 원심분리 후 감압여과 하였으며, 상등액을 농축 후 동결건조하여 수용성 다당류 추출물 생산을 위한 가수분 해물로 사용하였다.

\section{수용성 다당류 추출물의 분획}

효소가수분해물에 함유된 저분자 당류를 제거하기 위하여 $\operatorname{Im}$ 과 Yoon(2015)의 방법에 따라 알코올에 대한 용해도 차이 를 이용하여 수용성 다당류 추출물을 분리하였다. 즉, 최적 조건으로 효소가수분해 한 후 동결건조한 cellulose 분획과 hemicellulose 분획 가수분해물의 중량에 대한 20 배의 $99 \%$ 알 코올을 가하여 1 시간 동안 침지시킨 후, 원심분리(Supra-21K, Hanil)하여 얻어진 침전물을 동결건조하였다. 각 분획의 수용 성 다당류 추출물의 수율은 효소분해 전 분획의 중량 $(\mathrm{kg})$ 에 대한 수용성 다당류 추출물의 건조 중량 $(\mathrm{g})$ 으로 나타내었다.

\section{총폴리페놀 함량 측정}

폴리페놀 함량은 Folin과 Denis(1912) 법에 따라 측정하였 
다. 즉, 최적 흡광도를 나타내는 농도로 희석된 수용성 다당 류 추출물 $0.1 \mathrm{~mL}$ 와 Folin-Ciocalteu's phenol reagent 0.1 $\mathrm{mL}$ 를 가하여 잘 혼합하여 상온에서 3 분간 반응시켰다. 그 후 $10 \% \mathrm{Na}_{2} \mathrm{CO}_{3}$ 를 $0.2 \mathrm{~mL}$ 가하고 증류수 $2 \mathrm{~mL}$ 를 첨가하여 상 온에서 1 시간 방치한 후 $725 \mathrm{~nm}$ 에서 흡광도를 측정하였다.

\section{항산화 활성 측정}

들깨박 다당류 추출물의 hydroxyl 라디칼 소거능은 Gutteridege(1984)의 방법을 변형하여 측정하였다. 농도별로 희석한 식이섬유, $1 \mathrm{mM} \mathrm{FeSO}_{4}, 1 \mathrm{mM}$ EDTA, $10 \mathrm{mM}$ 2deoxyribose을 각각 $50 \mu \mathrm{L}$ 씩을 서로 반응시킨다. 반응액에 $0.1 \mathrm{M}$ phosphate buffer(pH 7.2) $300 \mu \mathrm{L}$ 와 $10 \mathrm{mM} \mathrm{H}_{2} \mathrm{O}_{2}$ 및 $1 \mathrm{mM}$ ascorbic acid를 각각 $50 \mu \mathrm{L}$ 를 가하여 $37^{\circ} \mathrm{C}$ 에서 1 시간 동안 반응시킨다. 반응액의 $250 \mu \mathrm{L}$ 를 취하여 $2.8 \%$ trichloroacetic acid(TCA) 용액 $500 \mu \mathrm{L}$ 를 가한 후, $1 \%$ thiobarbituric $\operatorname{acid}(\mathrm{TBA})$ 용액 $500 \mu \mathrm{L}$ 를 가하여 $100^{\circ} \mathrm{C}$ 에서 10 분간 가열시 킨 다음 이것을 급냉하여 $532 \mathrm{~nm}(\mathrm{U}-2900$, Hitachi, Tokyo, Japan)에서 흡광도를 측정하였다.

수용성 다당류 추출물의 환원력은 Mau 등(2002)의 방법을 변형하여 측정하였다. 농도별로 희석한 다당류 $100 \mu \mathrm{L}$ 를 e-tube에 취하여, $0.2 \mathrm{M}$ sodium phosphate buffer(pH 6.6) 및 $1 \%$ potassium ferricyanide $\left(\mathrm{KFe}(\mathrm{CN})_{6}\right)$ 를 각각 $100 \mu \mathrm{L}$ 씩 첨 가하여 $50^{\circ} \mathrm{C}$ 에서 25 분간 반응시킨 후 $10 \%$ trichloroacetic $\operatorname{acid}\left(\mathrm{CCl}_{3} \mathrm{COOH}\right) 100 \mu \mathrm{L}$ 를 첨가하였다. 위 반응액을 $25^{\circ} \mathrm{C}$, $16,400 \times g$ 에서 10 분간 원심분리한 상등액 $200 \mu \mathrm{L}$ 에 $0.1 \%$ ferric chloride $\left(\mathrm{FeCl}_{3} \cdot 6 \mathrm{H}_{2} \mathrm{O}\right) \quad 40 \mu \mathrm{L}$ 와 증류수 $40 \mu \mathrm{L}$ 를 microplate에서 반응시켜 microplate reader(EPOCH, BioTek, Winooski, VT, USA)로 $700 \mathrm{~nm}$ 에서 측정하였다.

들깨박 다당류 추출물의 superoxide dismutase(SOD) 유사 활성 측정은 Bradford(1976)의 방법에 준하여 측정하였다. 농도별로 희석한 시료 $50 \mu \mathrm{L}$ 를 microplate에 취하고, $\mathrm{pH} 8.5$ 로 보정한 tris- $\mathrm{HCl}$ buffer $(50 \mathrm{mM}$ tris [hydroxymethyl] amino-methane + $10 \mathrm{mM}$ EDTA) $200 \mu \mathrm{L}$ 와 $7.2 \mathrm{mM}$ pylrogallol $20 \mu \mathrm{L}$ 를 가하고 $25^{\circ} \mathrm{C}$ 에서 10 분간 반응시켰다. 반응을 정지시키기 위해 $1 \mathrm{~N} \mathrm{HCl} 10 \mu \mathrm{L}$ 를 가하여 microplate reader $(\mathrm{EPOCH}, \mathrm{BioTek})$ 로 $420 \mathrm{~nm}$ 에서 흡광도를 측정하였다.

\section{통계처리}

본 실험은 3 반복된 실험결과의 평균값과 표준편차로 나타 내었고, SPSS(Ver. 23, Chicago, IL, USA) 통계 프로그램을 통해 $\mathrm{p}<0.05$ 수준에서 일원배치 분산분석법을 시행하였으며, 실험군 간의 유의적 차이는 Duncan's multiple range test로 검증하였다.

\section{결과 및 고찰}

\section{분획물의 가수분해를 위한 효소 결정}

들깨박 분획물로부터 수용성 다당류 추출물 생산을 위한 가수분해 효소를 결정하기 위해 AMG 300, Celluclast $1.5 \mathrm{~L}$, Pectinex Ultra SP-L, Shearzyme plus 및 Viscozyme L로 효 소반응 후 얻은 가수분해물의 환원당 함량을 측정한 결과는 Table 2에 나타내었다. Cellulose 분획의 경우, Celluclast로 분해한 분해물의 환원당 함량이 $2.46 \mathrm{mg} / \mathrm{mL}$ 로 유의적으로 가장 높았고 $(\mathrm{p}<0.05)$, hemicelulose 분획의 경우 Viscozyme 으로 분해한 분해물의 환원당 함량 $(3.16 \mathrm{mg} / \mathrm{mL})$ 이 유의적 으로 가장 높아 $(p<0.05)$, 이들 각각을 식이섬유 생산을 위한 가수분해 효소로 결정하였다. 이는 메밀껍질로부터 올리고 당을 생산하기 위하여 여러 가지 세포벽분해효소를 이용하 여 cellulose 및 hemicellulose 분획을 분해한 결과 $(\mathrm{Im}$ 등, 2016), Celluclast로 분해한 cellulose 분획 가수분해물과 Viscozyme로 분해한 hemicellulose 가수분해물의 환원당 함 량이 가장 높은 것으로 나타난 연구결과와 일치하였다. 이러 한 결과는 cellulase 활성을 가진 Celluclast의 cellulose 분획에 대한 높은 작용력과 hemicellulase 및 xylanase 활성을 가진 Viscozyme의 hemicellulose 분획에 대한 넓은 작용력에 기인 한 것으로 판단된다.

\section{Celluclast을 이용한 cellulose 분획의 최적 분해조건}

들깨박으로부터 수용성 다당류 추출물을 생산하기 위한 최적 분해조건을 선정하기 위해 다양한 $\mathrm{pH}$, 온도 및 효소 농 도 하에서 cellulose 분획을 24시간 동안 분해하였으며, 각 가 수분해물의 환원당 함량을 측정한 결과를 Table 3 에 나타내 었다. 최적 $\mathrm{pH}$ 를 선정하기 위해 $\mathrm{pH}$ 3.0-7.0으로 조절하여 효 소분해 하였으며 생성된 환원당 함량을 측정한 결과, 효소분

Table 2. Reducing sugar content of enzymatic hydrolysates obtained from cellulose and hemicellulose fractions using various enzymes

$(\mathrm{mg} / \mathrm{mL})$

\begin{tabular}{ccc}
\hline Enzyme & $\begin{array}{c}\text { Cellullose } \\
\text { fraction }\end{array}$ & $\begin{array}{c}\text { Hemicellulose } \\
\text { fraction }\end{array}$ \\
\hline AMG 300 L & $1.70 \pm 0.05^{1) \mathrm{c} 2}$ & $2.47 \pm 0.03^{\mathrm{b}}$ \\
Celluclast 1.5 L & $2.46 \pm 0.08^{\mathrm{a}}$ & $1.44 \pm 0.03^{\mathrm{d}}$ \\
Pectinex Ultra SP-L & $1.69 \pm 0.05^{\mathrm{c}}$ & $1.90 \pm 0.03^{\mathrm{c}}$ \\
Shearzyme pluse & $1.96 \pm 0.04^{\mathrm{b}}$ & $1.28 \pm 0.04^{\mathrm{e}}$ \\
Viscozyme L & $1.71 \pm 0.05^{\mathrm{c}}$ & $3.16 \pm 0.02^{\mathrm{a}}$ \\
\hline
\end{tabular}

${ }^{1)}$ Mean \pm SD $(\mathrm{n}=3)$

${ }^{2)}$ Values with different letters in the column are significantly different at $\mathrm{p}<0.05$. 
Table 3. Effect of $\mathrm{pH}$, temperature and enzyme concentration on enzymatic hydrolysis of cellulose fraction

\begin{tabular}{ccc}
\hline Hydrolysis conditions & $\begin{array}{c}\text { Reducing sugar content } \\
(\mathrm{mg} / \mathrm{mL})\end{array}$ \\
\hline $\mathrm{pH}$ & 3 & $2.22 \pm 0.04^{1) \mathrm{c} 2)}$ \\
& 5 & $2.27 \pm 0.02^{\mathrm{b}}$ \\
& 6 & $2.64 \pm 0.04^{\mathrm{a}}$ \\
& 7 & $1.42 \pm 0.02^{\mathrm{d}}$ \\
\hline Temperature & 30 & $0.95 \pm 0.03^{\mathrm{e}}$ \\
\hline (C) & 40 & $1.51 \pm 0.04^{\mathrm{b}}$ \\
& 50 & $1.53 \pm 0.03^{\mathrm{b}}$ \\
& 60 & $1.75 \pm 0.02^{\mathrm{a}}$ \\
& 15 & $0.93 \pm 0.04^{\mathrm{c}}$ \\
\hline & 20 & $1.52 \pm 0.02^{\mathrm{d}}$ \\
& 25 & $1.91 \pm 0.02^{\mathrm{c}}$ \\
& 30 & $2.34 \pm 0.02^{\mathrm{b}}$ \\
Enzyme concentration & 35 & $2.65 \pm 0.03^{\mathrm{a}}$ \\
& & $2.66 \pm 0.01^{\mathrm{a}}$ \\
\hline
\end{tabular}

${ }^{1)}$ Mean \pm SD $(\mathrm{n}=3)$.

${ }^{2)}$ Values with different letters in the column are significantly different at $\mathrm{p}<0.05$.

해액 중 $\mathrm{pH} 5.0$ 일 때 환원당 함량이 $2.64 \mathrm{mg} / \mathrm{mL}$ 로 유의적으 로 가장 높았다 $(\mathrm{p}<0.05)$. 따라서 cellulose 분획의 효소분해 최적 $\mathrm{pH}$ 는 5.0 으로 결정하였으며, 최적 가수분해 온도를 선 정하기 위해 $\mathrm{pH} 5.0,30-60^{\circ} \mathrm{C}$ 에서 효소분해 하여 얻은 가수 분해물의 환원당 함량을 측정하였다. $50^{\circ} \mathrm{C}$ 일 때 유의적으로 가장 높은 환원당 함량 $(1.75 \mathrm{mg} / \mathrm{mL})$ 을 보였으며 $(\mathrm{p}<0.05)$, 그 다음으로 $30^{\circ} \mathrm{C}$ 및 $40^{\circ} \mathrm{C}$ 에서 $1.51 \mathrm{mg} / \mathrm{mL}$ 및 $1.53 \mathrm{mg} / \mathrm{mL}$ 로 유사한 함량을 보여, cellulose 분획의 효소분해 최적 온도는 $50^{\circ} \mathrm{C}$ 로 결정하였다. $\mathrm{pH} 5.0$ 와 $50^{\circ} \mathrm{C}$ 조건에서 최적 효소 농도 를 선정하기 위해 15 unit에서 35 unit까지 효소 농도를 달리 하여 반응 후 얻은 가수분해물의 환원당 함량을 측정한 결과, 효소 농도 30 unit과 35 unit일 때 각각 $2.65 \mathrm{mg} / \mathrm{mL}$ 및 2.66 $\mathrm{mg} / \mathrm{mL}$ 로 유의적으로 높은 환원당 함량을 나타냈다 $(\mathrm{p}<0.05)$. 따라서 들깨박으로부터 수용성 다당류 생산을 위해 효소 농 도는 농도 대비 효율성을 감안하여 30 unit으로 결정하였다. 잇꽃기름 추출 최적화 연구에서 Cellucalst의 최적 $\mathrm{pH}$ 는 4.5-5.0, 최적 온도는 $50^{\circ} \mathrm{C}$ 로 결정되어(Gibbins 등, 2012), 본 연구결과와 유사하였다. Cellulase의 활성은 작용기질에 따라 차이가 있지만, 일반적으로 미생물 유래 cellulase의 최적 온도 및 $\mathrm{pH}$ 는 각각 $40-60^{\circ} \mathrm{C}, \mathrm{pH}$ 4.5-6.0이다(Pardo과 Forchiassin,
1999). 본 연구에서의 선정된 Celluclast의 들깨박 최적 분해 조건은 cellulase의 최적 $\mathrm{pH}$ 및 최적 온도와 일치함을 알 수 있었으며, 이에 따라 들깨박 cellulose 분획에 대한 반응성이 높게 나타난 것으로 판단된다.

\section{Viscozyme을 이용한 hemicellulose 분획의 최적 분해조건}

들깨박 수용성 다당류 추출물 생산을 위한 최적 분해조건 을 선정하기 위해 $\mathrm{pH}$, 온도 및 효소 농도에 따라 hemicellulose 분획을 24 시간 분해하였으며, 각 가수분해물의 환 원당 함량을 측정한 결과는 Table 4에 나타내었다. 반응물의 $\mathrm{pH}$ 를 3.0에서 7.0까지 조절하여 24시간 동안 효소분해한 후 생성된 환원당 함량을 측정한 결과, $\mathrm{pH} 4.0$ 일 때 환원당 함량 이 $3.59 \mathrm{mg} / \mathrm{mL}$ 로 유의적으로 가장 높았다 $(\mathrm{p}<0.05)$. 따라서 hemicellulose 분획의 효소분해 최적 $\mathrm{pH}$ 는 4.0 으로 결정하였 다. $\mathrm{pH} 4.0$ 일 때 다양한 온도 하에서 생성된 가수분해물의 환 원당 함량을 측정한 결과, 반응온도 $50^{\circ} \mathrm{C}$ 일 때 $4.79 \mathrm{mg} / \mathrm{mL}$ 로 유의적으로 가장 높은 환원당 함량을 나타내었다 $(\mathrm{p}<0.05)$ 다음으로 $40^{\circ} \mathrm{C}(3.96 \mathrm{mg} / \mathrm{mL})$ 및 $60^{\circ} \mathrm{C}(3.95 \mathrm{mg} / \mathrm{mL})$ 에서 환원 당 함량이 유사하게 측정되어, hemicellulose 분획의 효소분 해 최적 온도를 $50^{\circ} \mathrm{C}$ 로 결정하였다. $\mathrm{pH} 4.0,50^{\circ} \mathrm{C}$ 조건에서

Table 4. Effect of pH, temperature and enzyme concentration on enzymatic hydrolysis of hemicellulose fraction

\begin{tabular}{ccc}
\hline Hydrolysis conditions & $\begin{array}{c}\text { Reducing sugar contents } \\
(\mathrm{mg} / \mathrm{mL})\end{array}$ \\
\hline pH & 3 & $3.28 \pm 0.04^{1 \mathrm{~b} 2)}$ \\
& 4 & $3.59 \pm 0.06^{\mathrm{a}}$ \\
& 5 & $2.89 \pm 0.03^{\mathrm{c}}$ \\
& 6 & $2.70 \pm 0.03^{\mathrm{d}}$ \\
\hline & 7 & $2.22 \pm 0.02^{\mathrm{e}}$ \\
\hline Temperature & 30 & $3.43 \pm 0.03^{\mathrm{c}}$ \\
& 40 & $3.96 \pm 0.05^{\mathrm{b}}$ \\
& 50 & $4.79 \pm 0.04^{\mathrm{a}}$ \\
& 60 & $3.95 \pm 0.03^{\mathrm{b}}$ \\
\hline & 15 & $4.03 \pm 0.04^{\mathrm{d}}$ \\
& 20 & $4.19 \pm 0.02^{\mathrm{c}}$ \\
& 25 & $4.46 \pm 0.06^{\mathrm{b}}$ \\
& 30 & $5.47 \pm 0.02^{\mathrm{a}}$ \\
& 35 & $5.48 \pm 0.03^{\mathrm{a}}$ \\
\hline
\end{tabular}

${ }^{1)}$ Mean \pm SD (n=3).

${ }^{2)}$ Values with different letters in the column are significantly different at $\mathrm{p}<0.05$. 
최적효소 농도를 선정하기 위해 15 unit에서 35 unit 범위로 효소 농도를 달리하여 분해하였다. Viscozyme 농도 30 unit 과 35 unit일 때, 각각 $5.47 \mathrm{mg} / \mathrm{mL}$ 및 $5.48 \mathrm{mg} / \mathrm{mL}$ 로 높은 함량을 나타내었으며, 두 효소 함량에서 유의적인 차이가 없 어 hemicellulose 분해를 위한 효소 농도는 효율성이 높은 30 unit으로 선정하였다. 이러한 결과는 귀리 겨의 단백질 생산을 위한 효소가수분해 시 Viscozyme의 최적조건이 $\mathrm{pH} 4.6$ 및 4 $4^{\circ} \mathrm{C}$ 로 나타난 결과(Liu 등, 2008)와 유사하였다. Viscozyme 은 대표적인 식물세포벽분해 복합효소로써 cellulase, $\beta$ glucanase, hemicellulase 및 xylanase의 효소활성을 가지며, 이들 효소가 식물의 세포벽에 존재하는 불용성의 고분자물질 을 분해 및 가용화함으로써 환원당 함량이 증가된 것으로 판 단된다(Oh 등, 2015)

\section{수율}

최적 가수분해 조건하에서 cellulose 및 hemicellulose 분획 을 0-72시간 동안 효소분해하여 얻은 수용성 다당류 추출물의 수율은 Table 5 와 같다. Cellulose 분획의 효소분해 전 수용성 다당류의 수율은 $142.2 \mathrm{~g} / \mathrm{kg}$ 이었으며, 48시간 효소분해하여 생 성된 식이섬유의 수율은 $160.2 \mathrm{~g} / \mathrm{kg}$ 으로 유의적으로 증가하였 다(p<0.05). 하지만 72시간 분해 후에는 $187.8 \mathrm{~g} / \mathrm{kg}$ 으로 48 시간 의 수율과 유의적 차이는 없었으며, 수율 증가율은 $132.1 \%$ 로 나타났다. Hemicellulose 분획의 효소분해 전 수율은 $33.8 \mathrm{~g} / \mathrm{kg}$ 이었으며, 72 시간동안 분해 후 수율은 $45.3 \mathrm{~g} / \mathrm{kg}$ 으로 효소분해 시간이 길수록 유의적으로 수율이 증가하였고 $(\mathrm{p}<0.05)$ 증가율 은 $134.0 \%$ 이었다. 전체 수율은 분해 전 $176.0 \mathrm{~g} / \mathrm{kg}$ 에서 72시간 분해 후 $233.1 \mathrm{~g} / \mathrm{kg}$ 으로 유의적으로 증가하였으며 $(\mathrm{p}<0.05)$, 총 수율 증가율은 $132.4 \%$ 로 나타났다. 이와 같은 결과는 효소분해 를 통한 배추 부산물이 분해시간이 경과함에 따라 수율도 함께 증가한 연구결과(Park과 Yoon, 2015)와 유사하였다.

\section{총폴리페놀 함량}

들깨박 수용성 다당류 추출물에 함유된 총폴리페놀 함량
을 측정한 결과는 Table 6과 같다. Cellulose 분획은 효소분 해에 의해 총폴리페놀 함량이 증가하였으며, 특히 24시간 효 소분해한 추출물의 총폴리페놀 함량 $(11.86 \mathrm{mgTA} / \mathrm{g})$ 은 효소 분해 전(6.36 mgTA $/ \mathrm{g})$ 에 비해 약 2 배 많았다. 하지만 48 시간 및 72 시간 효소분해 하여 얻은 다당류 추출물의 폴리페놀 함 량은 각각 $6.61 \mathrm{mgTA} / \mathrm{g}$ 및 $6.29 \mathrm{mgTA} / \mathrm{g}$ 으로 그 함량이 감 소하였다. 이러한 결과는 식물세포벽과 결합되어 있던 불용 성 폴리페놀 화합물이 효소에 의해 용출되어 그 함량이 증가 되었다가(Cinar, 2005), 일정 시간이상의 효소분해 시 다당류 와 결합되어 있던 페놀화합물이 유리 형태의 저분자로 전환 됨으로써 에탄올에 용해되어 제거된 것으로 판단된다.

Hemicellulose 분획의 경우 효소분해에 의해 총폴리페놀 함 량이 증가하였으며, 24시간 추출물의 함량이 $12.92 \mathrm{mgTA} / \mathrm{g}$ 으 로 유의적으로 가장 높았으며 $(\mathrm{p}<0.05), 48$ 시간 및 72 시간 분 해 후 얻은 추출물의 폴리페놀 함량은 각각 $12.11 \mathrm{mgTA} / \mathrm{g}$ 및 $12.11 \mathrm{mgTA} / \mathrm{g}$ 으로 높은 값을 유지하였다. 이와 같은 결과는 다양한 추출 방법으로 얻은 복분자 유래 폴리페놀의 함량을 측 정한 결과, 세포벽 분해효소를 이용한 추출물 $(24.6 \mathrm{mgTA} / \mathrm{g})$ 이 열수추출물(13.30 mgTA/g)에 비하여 유의적으로 높은 총폴 리페놀 함량을 보여 효소를 이용한 추출방법이 다량의 페놀

Table 6. Total polyphenol content of water-soluble polysaccharide extracts produced from perilla seed cake by enzymatic hydrolysis

$(\operatorname{mgTA} / \mathrm{g})$

\begin{tabular}{ccc}
\hline $\begin{array}{c}\text { Hydrolysis } \\
\text { time (h) }\end{array}$ & $\begin{array}{c}\text { Cellulose } \\
\text { fraction }\end{array}$ & $\begin{array}{c}\text { Hemicellulose } \\
\text { fraction }\end{array}$ \\
\hline 0 & $6.36 \pm 0.08^{1) \mathrm{c} 2}$ & $7.21 \pm 0.08^{\mathrm{c}}$ \\
24 & $11.86 \pm 0.08^{\mathrm{a}}$ & $12.92 \pm 0.05^{\mathrm{a}}$ \\
48 & $6.61 \pm 0.06^{\mathrm{b}}$ & $12.11 \pm 0.20^{\mathrm{b}}$ \\
72 & $6.29 \pm 0.11^{\mathrm{c}}$ & $12.11 \pm 0.05^{\mathrm{b}}$ \\
\hline
\end{tabular}

${ }^{1)}$ Mean \pm SD $(\mathrm{n}=3)$.

${ }^{2)}$ Values with different superscript letters in the same column are significantly different at $\mathrm{p}<0.05$.

Table 5. Yields of water-soluble polysaccharide extracts produced from perilla seed cake by enzymatic hydrolysis

\begin{tabular}{|c|c|c|c|}
\hline \multirow{2}{*}{ Hydrolysis time (h) } & \multicolumn{3}{|c|}{ Yield $(\mathrm{g} / \mathrm{kg})$ (increase ratio, \%) } \\
\hline & Cellulose fraction & Hemicellulose fraction & Total \\
\hline 0 & $142.2 \pm 9.3^{1) \mathrm{c} 2)}(100.0)$ & $33.8 \pm 0.9^{\mathrm{d}}(100.0)$ & $176.0 \pm 5.3^{\mathrm{d}}(100.0)$ \\
\hline 24 & $160.2 \pm 8.4^{\mathrm{b}}(112.7)$ & $37.1 \pm 1.4^{\mathrm{c}}(109.8)$ & $197.3 \pm 4.6^{\mathrm{c}}(113.1)$ \\
\hline 48 & $182.7 \pm 4.1^{\mathrm{a}}(128.5)$ & $40.7 \pm 0.3^{\mathrm{b}}$ & $223.4 \pm 2.1^{\mathrm{b}}(123.9)$ \\
\hline 72 & $187.8 \pm 6.7^{\mathrm{a}}(132.1)$ & $45.3 \pm 1.7^{\mathrm{a}}(134.0)$ & $233.1 \pm 2.6^{\mathrm{a}}(132.4)$ \\
\hline
\end{tabular}

${ }^{1)} \mathrm{Mean} \pm \mathrm{SD}(\mathrm{n}=3)$.

${ }^{2)}$ Values with different superscript letters in the same column are significantly different at $\mathrm{p}<0.05$. 
화합물을 용출에 효과적인 것으로 보고된(Ryu와 Kwon, 2013) 결과와 유사하였다. 이상의 결과에서 들깨박으로부터 얻은 수용성 다당류 추출물의 총폴리페놀 함량은 효소분해 시 증가하였지만, 48시간 이상 지속될 경우 오히려 감소하는 것을 확인되었다. 따라서 기능성 식품소재로 들깨박으로부터 수용성 다당류 추출물을 얻기 위해서는 사용될 경우 사용 목 적에 따라 효소분해시간을 조절할 필요가 있을 것으로 판단 된다.

\section{항산화 활성}

효소분해에 의해 들깨박으로부터 얻은 수용성 다당류 추출 물의 항산화 활성을 측정하기 위해 hydroxyl 라디칼 소거능, 환원력 및 $\mathrm{SOD}$ 유사활성을 측정하였으며, 이들의 $\mathrm{IC}_{50}$ 값을 Table 7에 나타내었다. 항산화력은 cellulose 및 hemicellulose 분획 모두 24시간 분해 시 가장 낮은 $\mathrm{IC}_{50}$ 값을 나타내었다. Hydroxyl 라디칼 소거능은 분해 전 cellulose 및 hemicellulose 분획의 $\mathrm{IC}_{50}$ 은 각각 $3.37 \mathrm{mg} / \mathrm{mL}$ 와 $4.73 \mathrm{mg} / \mathrm{mL}$ 였고, 가수분 해에 의해 소거능이 증가하였으며, 특히 24시간 분해 후에는 각각 $2.02 \mathrm{mg} / \mathrm{mL}$ 와 $1.16 \mathrm{mg} / \mathrm{mL}$ 로 가장 낮은 $\mathrm{IC}_{50}$ 값을 나타 내었다. Liu 등(2008)은 초음파 추출을 이용하여 Hovenia dulcis 꽃받침으로부터 얻은 다당류의 hydroxy 라디칼 소거 능을 측정한 결과, $1-4 \mathrm{mg} / \mathrm{mL}$ 농도에서 $13.23-23.69 \%$ 의 소 거능을 나타난다고 보고하여, 들깨박으로부터 얻은 다당류 추출물이 높은 hydroxy 라디칼 소거능을 나타냄을 알 수 있 었다. Hydroxyl 라디칼은 금속이온과 $\mathrm{H}_{2} \mathrm{O}_{2}$ 가 반응하여 생성 된 발암물질로, DNA의 변형 및 malonaldehyde를 분해시킨 다(Aruoma와 Cuppett, 1997). 이에 들깨박 수용성 다당류 추 출물은 hydroxyl 라디칼 소거물질을 함유하며, 유전물질 변
성 및 산화반응을 억제시키는 능력이 있을 것으로 판단된다. 환원력은 cellulose 분획의 경우 24시간 분해 후 0.6 $\mathrm{mg} / \mathrm{mL}$ 로 가장 낮은 $\mathrm{IC}_{50}$ 값을 보였으며, 분해시간이 증가할 수록 값은 증가하였으나, 분해 0시간에 비해 높은 환원력을 나타내었다. Hemicellulose 분획의 환원력은 24시간 분해 후 $0.82 \mathrm{mg} / \mathrm{mL}$ 로 가장 낮은 $\mathrm{IC}_{50}$ 값을 보였으며, 분해시간이 길 어질수록 환원력은 낮아졌다. 해송이버섯의 환원력을 측정한 결과, $1 \mathrm{mg} / \mathrm{mL}$ 열수추출물농도에서 환원력이 0.17 로 나타나 (Xu 등, 2007), 효소분해에 의해 얻은 들깨박 수용성 식이섬 유 추출물이 우수한 환원력을 가진 것으로 나타났다. 또한 효 소추출한 오만둥이 다당류는 $5 \mathrm{mg} / \mathrm{mL}$ 에서 0.264 의 환원력 을 보였으며, 이는 열수추출물(0.122) 및 고압증기원리 추출 물(0.0-0.2)보다 유의적으로 높아 효소분해가 환원물질 용출 이 용이한 것으로 보고되었다(Lee와 Hong, 2014). 효소에 의 해 생성된 오만둥이 다당류의 환원력은 $1 \mathrm{mg} / \mathrm{mL}$ 의 농도에 서 0.2 이하로 보고되어(Zha 등, 2009), 본 연구의 들깨박 다 당류 추출물에 비해 매우 낮은 환원력을 보였다.

들깨박 수용성 다당류의 SOD 유사활성을 측정한 결과, celullose 및 hemicellulose 분획 모두 24시간 분해 후 가장 높은 활성을 보였다. 특히, cellulose 분획의 경우, 가수분해에 의해 그 활성이 증가하였으며, hemicellulose 분획의 경우에 는 24 시간 및 48 시간 가수분해에 의해 활성이 증가되었다. $\mathrm{SOD}$ 는 세포에 존재하여 superoxide를 과산화수소 및 산소의 전환 반응을 유도하여 활성산소로부터 세포를 방어하는 중요 인자이다(Kim과 Choi, 2008). 따라서 효수가수분해에 의해 생산된 들깨박 다당류 추출물은 체내에서 superoxide 제거함 으로써 활성산소로부터 세포를 보호하는 역할을 할 수 있을 것으로 판단된다.

Table 7. Antioxidant activity of water-soluble polysaccharide extracts produced from perilla seed cake by enzymatic hydrolysis

\begin{tabular}{|c|c|c|c|c|}
\hline \multirow{2}{*}{ Fraction } & \multirow{2}{*}{ Hydrolysis time (h) } & \multicolumn{3}{|c|}{$\mathrm{IC}_{50}$ value $(\mathrm{mg} / \mathrm{mL})$} \\
\hline & & $\begin{array}{l}\text { Hydroxyl radical } \\
\text { scavenging activity }\end{array}$ & Reducing power & SOD-like activity \\
\hline \multirow{4}{*}{ Cellulose } & 0 & $3.37 \pm 0.21^{1) \mathrm{c} 2)}$ & $1.18 \pm 0.01^{\mathrm{d}}$ & $8.20 \pm 0.51^{\mathrm{c}}$ \\
\hline & 24 & $2.02 \pm 0.06^{\mathrm{a}}$ & $0.60 \pm 0.00^{\mathrm{a}}$ & $3.23 \pm 0.77^{\mathrm{a}}$ \\
\hline & 48 & $2.20 \pm 0.08^{\mathrm{a}}$ & $0.91 \pm 0.03^{b}$ & $5.54 \pm 0.24^{\mathrm{b}}$ \\
\hline & 72 & $2.64 \pm 0.15^{\mathrm{b}}$ & $1.07 \pm 0.11^{\mathrm{c}}$ & $5.88 \pm 0.81^{\mathrm{b}}$ \\
\hline \multirow{4}{*}{ Hemicellulose } & 0 & $4.73 \pm 0.13^{\mathrm{d}}$ & $1.06 \pm 0.00^{\mathrm{c}}$ & $3.62 \pm 0.57^{b}$ \\
\hline & 24 & $1.16 \pm 0.11^{\mathrm{a}}$ & $0.82 \pm 0.00^{\mathrm{a}}$ & $1.46 \pm 0.28^{\mathrm{a}}$ \\
\hline & 48 & $2.69 \pm 0.39^{\mathrm{b}}$ & $1.03 \pm 0.01^{\mathrm{b}}$ & $2.99 \pm 0.28^{\mathrm{b}}$ \\
\hline & 72 & $3.12 \pm 0.19^{\mathrm{c}}$ & $1.13 \pm 0.00^{\mathrm{d}}$ & $5.26 \pm 0.54^{\mathrm{c}}$ \\
\hline
\end{tabular}

${ }^{1)} \mathrm{Mean} \pm \mathrm{SD}(\mathrm{n}=3)$

${ }^{2)}$ Values with different superscript letters in the same column are significantly different at $\mathrm{p}<0.05$. 


\section{요 약}

본 연구는 식품 가공부산물의 기능성 식품소재로 활용하 기 위해 들깨박을 cellulose 및 hemicellulose 분획으로 나누 고, 효소적 가수분해를 하여 이들 분획으로부터 기능성을 가 진 수용성 다당류 추출물을 생산하고자 하였다. 이를 위해 먼 저 효소분해조건을 선정하고, 가수분해시간에 따라 생산된 수 용성 다당류 추출물의 항산화 활성을 측정하였다. Cellulose 분획의 효소가수분해 최적 조건은 $\mathrm{pH} 5.0,50^{\circ} \mathrm{C}$ 및 Celluclast 농도 30 unit이었으며, hemicellulose 분획의 경우 $\mathrm{pH} 4.0,50^{\circ} \mathrm{C}$ 및 Viscozyme 농도 30 unit로 결정되었다. 최적 조건하에서 얻은 cellulose 분획의 수용성 다당류 추출물의 수율은 분해 시간이 경과할수록 증가하였으나, 72 시간 분해 시에는 유의 적인 증가는 없었다. 반면 hemicellulose 분획은 효소분해시간 이 경과할수록 수율이 유의적으로 증가하였다. 들깨박 수용성 다당류 추출물의 폴리페놀 함량은 cellulose 및 hemicellulose 분획 모두 24시간 효소분해한 경우, 각각 $11.86 \mathrm{mgTA} / \mathrm{g}$ 과 $12.92 \mathrm{mgTA} / \mathrm{g}$ 으로 가장 높았으며, 또한 항산화 활성도 가장 높게 나타났다. 이상의 결과, 효소적 분해에 의해 들깨박으로 부터 항산화 활성을 가진 수용성 다당류 추출물을 생산할 수 있었으며, 생산된 추출물은 식품산업에서 기능성 소재로 활 용가능할 것으로 판단된다.

\section{Conflict of interests}

The authors declare no potential conflict of interest.

\section{ORCID}

Yeo Jin Hwang https://orcid.org/0000-0002-8031-7686 Ja Min Kim https://orcid.org/0000-0002-2565-6087 Kyung Young Yoon

https://orcid.org/0000-0003-0626-5563

\section{References}

Aruoma OI, Cuppett SL. Antioxidant Methodology: In Vivo and In Vitro Concepts: The American Oil Chemists Society, Urbana, IL, USA, Chapter 1, p 14-20 (1997)

Bradford MM. A rapid and sensitive method for the quantitation of microgram quantities of protein utilizing the principle of protein-dye binding. Anal Biochem, 72, 248-254 (1976)

Choi IJ, Kim YA. Effect of addition of dietary fibers on quality of Backsulgies. Korean J Soc Food Sci, 8, 281289 (1992)

Di Bernardini R, Harnedy P, Bolton D, Kerry J, O’Neill E, Mullen AM, Hayes M. Antioxidant and antimicrobial peptidic hydrolysates from muscle protein sources and by-products. Food Chem, 124, 1296-1307 (2011)

Folin O, Denis W. On phosphotungstic-phosphomolybdic compounds as color reagents. J Biol Chem, 12, 239-243 (1912)

Gibbins RD, Aksoy HA, Ustun G. Enzyme-assisted aqueous extraction of safflower oil: optimisation by response surface methodology. Int J Food Sci Technol, 47, 10551062 (2012)

Cinar I. Effect of cellulase and pectinase concentrations on the colour yield of enzyme extracted plant carotenoids. Process Biochem, 40, 945-949 (2005)

Gutteridge JMC. Reactivity of hydroxyl and hydroxyl-like radicals discriminated by release of thiobarbituric acidreactive material from deoxy sugars, nucleosides and benzoate. Biochem J, 224, 761-767 (1984)

Hwang YJ, Yoon KY. Enzymatic hydrolysis of perilla seed meal yields water-soluble dietary fiber as a potential functional carbohydrate source. Food Sci Biotechnol, 29, 987-996 (2020)

Im HJ, Park BY, Yoon KY. Production of soluble dietary fiber of buckweat hulls by enzymatic depolymerzation and its characteristics. Korean J Food Sci Technol, 48, 97-103 (2016)

Im HJ, Yoon KY. Production and characterisation of alcohol-insoluble dietary fibre as a potential source for functional carbohydrates produced by enzymatic depolymerisation of buckwheat hulls. Czech J Food Sci, 33, 449-457 (2015)

Kim JM, Liceaga AM, Yoon KY. Purification and identification of an antioxidant peptide from perilla seed (Perilla frutescens) meal protein hydrolysate. Food Sci Nutr, 7, 1645-1655 (2019)

Kim JS, Choi SY. Physicochemical properties and antioxidative activities of Omija (Schizandra chinensis Bailon). Korean J Food Nutr, 21, 35-42 (2008)

Lee DH, Hong JH. Physicochemical properties and antioxidant activities of polysaccharides from Styela plicata by extraction conditions. J Chitin Chitosan, 19, 130-137 (2014) 
Lee EH, Lee SH, Cho YJ. Biological activities of extracts from Cornus kousa fruit. J Appl Biol Chem, 58, 317323 (2015)

Lee YN, Song BR, Ju JH. Anti-inflammatory activity of Perilla frutescens Britton seed in RAW 264.7 macrophages and an ulcerative colitis mouse model. Korean J Food Sci Technol, 46, 61-67 (2014)

Lee DH, Hong JH. Biological activities and physicochemical properties of polysaccharides from Gloiopeltis furcata prepared by using various enzymes. Korean J Food Preserv, 24, 455-463 (2017)

Lembo A, Camilleri M. Chronic constipation. N Engl J Med, 349, 1360-1368 (2003)

Liu J, Guan X, Zhu D, Sun J. Optimization of the enzymatic pretreatment in oat bran protein extraction by particle swarm optimization algorithms for response surface modeling. LWT-Food Sci Technol, 41, 1913-1918 (2008)

Mau JL, Lin HC, Song SF. Antioxidant properties of several specialty mushrooms. Food Res Int, 35, 519-526 (2002)

Ministry of Food and Drug Safety. Food and Food Additives Production Performance in 2010. https://www.mfds.go.kr /brd/m_374/view.do?seq=11894 (accessed August 2020)

Ministry of Food and Drug Safety. Food Production Performance Statistics in 2019. https://www.mfds.go.kr/brd/m 374/view.do?seq=30200 (accessed August 2020)

Moon H, Ha K, Song YJ. High fiber and high carbohydrate intake and its association with the metabolic disease using the data of KNHANES 2013 2017. J Nutr Health, 52, 540-551 (2019)

Oh MH, Jang HL, Lim YJ, Yoon KY. Antioxidant activities of Cedrela sinensis hydrolysates prepared using various enzymes. Korean J Food Sci Technol, 47, 413-418 (2015)

Pardo AG, Forchiassin F. Influence of temperature and $\mathrm{pH}$ on cellulase activity and stability in Nectria catalinensis. Rev Argent Microbiol, 31, 31-35 (1999)

Park SY, Yoon KY. Enzymatic production of soluble dietary fiber from the cellulose fraction of Chinese cabbage waste and potential use as a functional food source. Food Sci Biotechnol, 24, 529-535 (2015)

Ryu IH, Kwon TO. Optimization of macerating enzymatic extraction precess and components change of extract of Rubus coreanus Miq. fruit. Korean J Med Crop Sci, 21, 97-104 (2013)

$\mathrm{Xu} \mathrm{XM}$, Jun JY, Jeong IH. A study on the antioxidant activity of Hae-Songi mushroom (Hypsizigus marmoreus) hot water extracts. J Korean Soc Food Sci Nutr, 36, 1351-1357 (2007)

Zha XQ, Wang JH, Yang XF, Liang H, Zhao LL, Bao SH, Luo JP, Xu YY, Zhou BB. Antioxidant properties of polysaccharide fractions with different molecular mass extracted with hot-water from rice bran. Carbohydr Polym, 78, 570-575 (2009) 